\title{
O JUDAÍSMO VETEROTESTAMENTÁRIO A PARTIR DA VISÃO MAQUIAVELIANA DA RELIGIÃO
}

\author{
Marcone Costa Cerqueira ${ }^{1}$ \\ Universidade Federal de Santa Catarina (UFSC) \\ (i) https://orcid.org/0000-0003-4539-3840
}

\begin{abstract}
RESUMO:
Neste artigo intentamos empreender uma leitura do judaísmo antigo, ou veterotestamentário, em alguns de seus aspectos principais, à contraluz da visão maquiaveliana do papel da religião na organização e expansão do Estado. O primeiro passo desta empresa será dado ao expormos os traços fundantes e delineadores da tradição judaica antiga, principalmente nos livros que compõe o chamado velho testamento, demonstrando o uso da religião na ordenação e expansão do Estado, bem como na formação do indivíduo. Em um segundo momento demonstraremos como se cria uma nova tradição judaica, influenciada e influenciadora do mundo grego antigo, logo no início da era cristã a qual será assimilada e explorada em seu viés místico no humanismo renascentista. Esta tradição judaico helenístico será a mais conhecida e assimilada nos círculos eruditos europeus da renascença. Por fim, buscaremos demonstrar como os traços constitutivos do judaísmo antigo, em detrimento ao judaísmo helenístico, podem ser lidos à luz da descrição maquiaveliana do papel da religião na organização e expansão do Estado e na formação do indivíduo.
\end{abstract}

PALAVRAS-CHAVE: Judaísmo; Maquiavel; Religião; Política.

\section{THE VETEROTESTAMENTARY JUDAISM IN MACHIAVELLIAN VIEW OF RELIGION}

\begin{abstract}
:
In this article we intend undertake a reading of ancient judaism, or veterotestamentary, in some of its main aspects, in contrast to the Machiavellian view of the role of religion in the organization and expansion of the State. The first step of this enterprise will be given by exposing the founding and delineanting features of the ancient Jewish tradition,
\end{abstract}

1 Doutorando em Filosofia na Universidade Federal de Santa Catarina (UFSC), Santa Catarina - Brasil. Bolsista Capes. E-mail: markantfilos@yahoo.com.br.

O judaísmo veterotestamentário a partir da visão maquiaveliana da religião - Marcone Costa Cerqueira 
especially in the books that make up the so-called Old Testament, demonstranting the using of religion in the ordination and expansion of the State, as well as in the formation of the individual. In a second moment we will demonstrate how to create a new Jewish tradition, influenced and influential on the ancient Greek world, early in the Christian era which will be assimilated and explored in its mystical bias in Renaissance humanism. This Hellenistic Judaism tradition will be best known and assimilated in the European erudite circles of the Renaissance. Finally, we will try to demonstrate how the constitutive features of ancient Judaism, to the detriment of Hellenistic Judaism, can be read in the light of Machiavellian description of the role of religion in the organization and expansion of the State and the formation of the individual.

KEYWORDS: Judaism; Machiavelli; Religion; Politic.

\section{Introdução}

A crítica maquiaveliana à religião cristã, a partir da leitura que lhe é dada em sua época, suscita ponderações e interpretações diversas por parte de seus leitores. Este movimento é fomentado por diversas inserções, esparsas ou em conjunto, de observações que o florentino fez sobre o papel da religião na vida do Estado e na organização social. Em nenhum momento Maquiavel trata do judaísmo especificamente, a não ser quando fala de Moisés e sua saga com o povo de Israel. No entanto, a partir do que ele indica ser o papel da religião na construção do caráter cívico dos indivíduos, os rituais religiosos que causam impressão, temor e ordem política no seio social, e por fim, a forma como ele indica o uso da religião na organização e fortalecimento da pátria, podemos fazer uma leitura dos traços marcantes do judaísmo veterotestamentário.

Neste sentido, o primeiro passo será apresentar a diferença entre o judaísmo veterotestamentário de Jerusalém, antes do período inter-bíblico, e o judaísmo helenístico, ou posterior à diáspora, influenciado pelas correntes sapienciais, principalmente de Alexandria. Buscaremos aqui apresentar a diferença de constituição da leitura sobre o papel da religião na vida política do povo judeu e suas implicações e assimilações do mundo ocidental grecoromano. Em seguida, num segundo passo, apresentaremos o que foi a absorção e influência deste judaísmo helenístico, ou sapiencial, no mundo intelectual da Europa medieval e renascentista, principalmente por meio da mística. Será necessário aludir a autores como Pico della Mirandola, cuja influência dos textos hebraicos é claramente percebida. No entanto, ainda será preciso entender como a cultura europeia no fim do medievo assimilava e compreendia a cultura judaica e sua construção teológico-política em detrimento ao cristianismo. 
Enfim, no terceiro movimento de nossa argumentação, demonstraremos como o judaísmo veterotestamentário está próximo das descrições, e prescrições, do que deva ser o papel da religião na construção do espírito cívico, da ordem política e do fortalecimento da pátria segundo Maquiavel. Tomaremos aqui dois eixos centrais, a formação dos indivíduos e o papel do ordenamento religioso e seus rituais no processo de ordenamento político da sociedade e defesa da pátria. Certamente não entraremos nos meandros teológicos ou místicos da religião judaica, a não ser nos momentos em que seja necessário demonstrar a mudança de perspectiva em relação ao ordenamento político. O cerne de nossa argumentação será exatamente demonstrar como a religião judaica veterotestamentária coaduna-se à descrição maquiaveliana dos traços religiosos que auxiliam na formação de um corpo político coeso e voltado para a defesa e expansão da pátria. Esta orientação da religião judaica antiga se mostrará mais próxima das religiões pagãs grega e romana do quê daquele cristianismo desenvolvido e praticado na época de Maquiavel.

\section{0 judaísmo antigo}

Seria necessário uma extensa análise histórica para se poder assentar, em todos os seus aspectos, as mudanças sofridas pela religião judaica em seus mais de 4.000 anos de existência. No entanto, dois períodos podem ser minimamente delineados, o período antigo, ou veterotestamentário ${ }^{2}$, que se estende do pentateuco até os profetas menores, e o período helenístico, que começa após a diáspora ocorrida logo depois da destruição do segundo templo pelos romanos no século I ${ }^{3}$. Entre estes dois períodos está o que se costuma chamar, na tradição cristã, de período inter-bíblico, ou seja, o período de transição entre o antigo testamento, desde o fim da época dos profetas, até o período que se inicia, já na tradição cristã, com o novo

\footnotetext{
2 De início, é necessário deixar claro que no judaísmo não existe uma distinção entre velho testamento e novo testamento, essas nomenclaturas fazem parte da tradição cristã, uma vez que os judeus não reconhecem o chamado novo testamento e nomeiam diferentemente o conjunto dos livros que compõem o chamado velho testamento. Na tradição judaica tem-se o pentateuco (os cinco primeiros livros dados por Deus à Moisés), os livros históricos (que contam as histórias dos reis de Israel e de seus reinados), os livros poéticos (como os Salmos), os livros sapienciais (como provérbios) e por fim os livros proféticos (dividido entre os profetas maiores e menores que profetizaram durante os períodos de exílio do povo de Israel). Usamos aqui o termo Veterotestamentário exatamente por ser esta a nomenclatura mais conhecida e utilizada na teologia ocidental, mas usaremos também o termo judaísmo antigo.

3 É certo que os judeus tiveram contato com os gregos ainda na época de Alexandre o Grande, como comenta Shäfer: Uma visita de Alexandre à Jerusalém é atestada tanto por Josefo quanto pela literatura rabínica. (SHÄFER, 1989, p. 20). No entanto, o povo judeu não seria ainda influenciado em sua religião, e seus costumes, por este contato com os gregos, apenas após a diáspora e o início da tradição sapiencial fora de Jerusalém este processo se intensificaria.
} 
testamento, durando cerca de 400 anos. Neste período a Palestina passou pela dominação babilônica, grega e assíria, até a dominação romana em 63 a.C.

No final do século I a.C, o reino próspero de Davi e Salomão é apenas um vulto presente nos escritos dos livros históricos do velho testamento e uma esperança ainda viva na promessa do Messias que o restauraria. No entanto, após séculos sob tantas dominações estrangeiras e exílios, vendo sua promessa messiânica se tornar o ancoradouro de uma nova religião, o judaísmo antigo começa a se direcionar para uma mudança dramática. A promessa do Messias sempre foi uma profecia de cunho político que anunciava a vinda daquele que restauraria a casa de Davi e a glória de seu reinado. Mas, a religião cristã que surge das raízes judaicas tem como líder um messias que prega a não-violência e a valorização do reino divino em detrimento ao reino terreno, um Messias não-político.

Esta discrepância entre as imagens dos dois arquétipos que surge da mesma profecia messiânica irá se acentuar após a conversão de Constantino ao cristianismo. Como comenta Neusner:

Desde que os judeus como um todo, e os sábios entre eles, anteciparam a vinda do Messias prometido pelos profetas, o problema pode ser facilmente apreciado. Se a história prova as proposições, como os profetas e os visionários apocalípticos tinham sustentado, então como podem os judeus negarem a reivindicação cristã de que a conversão do imperador, bem como do império, demonstravam o verdadeiro estado de relação entre o céu e a terra? (NEUSNER, 1987, p. 59.)

O movimento de mudança na configuração do judaísmo antigo se dará principalmente a partir da destruição do segundo templo em 70 d.C pelos romanos, o que causa o aumento de uma grande dispersão do povo judeu através de áreas do Oriente Médio, Mediterrâneo, África e Europa. Esta dispersão ficou conhecida como diáspora. Alexandria era um dos grandes centros da época, sendo certamente um dos lugares aos quais os judeus dispersos se direcionaram. Diversas outras cidades gregas se tornaram polos culturais e comerciais do mundo antigo antes da era cristã. Neste cenário a fusão entre a cultura grega e a cultura judaica formou a tradição conhecida como judaísmo helenístico, sendo o início da tradição sapiencial e o grande momento de fortalecimento de uma mística hebraica, próxima dos moldes ocidentais. Segundo Campos:

Houve, pois, duas tendências judias no mundo de após Alexandre. De um lado a mentalidade ferrenha dos judeus beatos de Jerusalém, e das pequenas aldeias palestinas puramente judaicas, que se queriam fechar a toda e qualquer concessão à cultura helena, de outro a das colônias judias das cidades gregas, que se deixavam penetrar não somente por sangue estrangeiro, como pelas ideias dos dominadores 
intelectuais do mundo. Os primeiros tentavam judaizar o que raramente lhes chegava da civilização helenística, os segundos, ao contrário, iam grecizando, como podiam, as velhas tradições a que se conservavam fiéis. (CAMPOS, 1961, p. 245)

"A mística hebraica, não diversamente da grega e da cristã, é um conjunto de fenômenos históricos determinados e concretos". (SCHOLEM, 1993, p. 19). Sendo assim, pode-se asseverar que a tradição judaico helenística, surgida no século I da era cristã em Alexandria com o fortalecimento da mística hebraica, é fruto dos acontecimentos históricos e políticos ocorridos na Palestina durante mais de 400 anos. A perda da referência religiosa do templo de adoração, destruído pelos romanos, os séculos sob o jugo da dominação de outras nações e o desvirtuamento da promessa messiânica, fizeram com que o judaísmo antigo, veterotestamentário, desse lugar a um judaísmo mais centrado nos aspectos místicos de religiosidade.

O judaísmo antigo continua a ser uma religião nacionalista, com forte cunho político e ampla ligação entre o político e o religioso. No entanto, é a religião nacionalista de um povo sem Estado, ou melhor, sem um domínio territorial próprio. Os judeus que continuaram em Jerusalém após a destruição romana tiveram que aceitar a presença de outros povos palestinos. "As nações do antigo Oriente próximo que estavam na vizinhança dos judeus, tinham símbolos específicos e bem definidos de um nacionalismo político, nomeadamente, o templo, o território, o reino e o exército.” (MENDELS, 1991, p. 1). A ligação do judaísmo com a influência intelectual grega cria um sincretismo que modificará não só o foco do culto judaico, mas, também todo o arranjo ético-político que constituía a base do judaísmo antigo. Weber nos dá uma indicação desta influência:

O judaismo antigo, bem como o farisaísmo, ignoravam totalmente o dualismo entre o espírito e a matéria, o espírito e o corpo, ou a pureza divina e a corrupção do mundo, elaborada pelo intelectualismo helenístico; o neoplatonismo tinha erigido o dualismo em um sistema onde o corpo não era mais que o envólucro da alma, uma realidade degradante. Certos círculos intelectuais judaico-helenísticos (Philon) tomaram emprestado o dualismo, e o cristianismo de Paulo, e fizeram sua visão ética do mundo. Tudo isso é estranho ao judaismo farisaico e talmúdico. (WEBER, 1970, p. 522).

Em vista desta mudança tão significativa na história da religião judaica, é preciso compreender o que era o judaísmo antigo, veterotestamentário, e como ele articulava a relação entre política e religião, principalmente a partir de suas bases de sustentação, a saber: a tradição, a formação do indivíduo e a defesa da nação. Certamente que a principal fonte para esta compreensão são os livros históricos e os livros da lei. Como já aludido acima, esta tradição ficou mantida, de forma mais restrita, aos 
círculos judaicos que permaneceram em Jerusalém e aqueles que não foram influenciados diretamente pela tradição helenística.

O ponto central do judaísmo veterotestamentário, é a tradição contida na Torá, livros dados diretamente por Deus à Moisés no Sinai, juntamente com a tradição oral. Seu núcleo se constitui dos cinco primeiros livros do chamado velho testamento, ou seja, o Pentateuco, os livros da lei. Segundo a tradição, a Torá foi dada ao povo de Israel como forma de expressar a vontade de Deus para o povo ao qual ele elegeu como seu na terra. Além disso, segundo a tradição, o povo de Israel aceitou ser o povo escolhido de Deus, mostrando sua diferença em relação aos demais povos da terra. Isto está bem claro na tradição, como se lê no seguinte trecho da Sifré:

Somente Israel quis tomar a Torá: Quando o Santo, bendito seja, se manifestou para dar a lei à Israel, a revelou não somente à Israel, mas antes a todos os outros povos. Primeiro foi aos filhos de Esaù e perguntou-lhes: Quereis tomar consigo a Torá? Eles disseram: Que coisa está escrito nela? Deus respondeu: Não matarás (Exôdo 20:13). Mas os filhos de Esaù disseram: Senhor do mundo, foi a natureza de nosso progenitor ser assassino, como está escrito (Gênesis 27:22): As mãos são as mãos de Esaù e (Gênesis 27:40): Viverás da tua espada. Não podemos tomar conosco a Torá. Deus andou aos Amonitas e aos Moabitas e perguntou-lhes: Quereis tomar consigo a Torá? Eles disseram: O que está escrito nela? Deus respondeu: Não cometerás adultério! (Exôdo 20:14). Mas os Amonitas e os Moabitas disseram: Senhor do mundo, nós temos origine na luxúria, como está escrito (Gênesis 19:36): Assim as duas filhas de Lot conceberam de seu pai. Nós não podemos tomar conosco a Torá. Depois Deus foi aos Ismaelitas e lhes disse: Quereis tomar consigo a Torá? Eles disseram: O que está escrito nela? Deus respondeu: Não roubarás! (Exôdo 20:15). Mas os Ismaelitas disseram: Senhor do mundo, foi a natureza de nosso progenitor ser um ladrão, como está escrito (Gênesis 16:12): Serás um selvagem; a sua mão será contra todos e a mão de todos contra ti. Nós não podemos tomar conosco a Torá. E assim Deus foi de uma nação à outra oferecendo a Torá, mas nenhuma queria ter a Torá. Só ao fim chegou aos Israelitas. Sem perguntar que coisa estava escrito na Torá, os Israelitas responderam rapidamente: Seguiremos e compreenderemos tudo o que tem dito o Senhor. (Da Sifré al Deuteronomio, Pisqa 343, ed. Finkelstein, pág. 395 - 397; cfr. Pesiqta Rabbathi 21, ed. Friedmann, p. 99b. Apud. PETUCHOWSKI, 1983, pág. 74 - 75.)

Um forte sentimento de identidade nacional se expressa nessa realidade de pertença à vontade de Deus, tornando a Torá um referencial para a construção de costumes, leis mais abrangentes e de organização política do povo. Ao contrário de outros povos da antiguidade, como os 
romanos e os gregos que estabeleceram forte sincretismo religioso e cultural em suas organizações sociais com outros povos, os judeus buscavam demarcar as suas origens apenas na vontade divina, desvencilhado-se de qualquer sincretismo cultural ou religioso. No entanto, assim como os romanos tinham o mos maiorum e os gregos a paidéia, os judeus tinham na tradição da Torá e de seus ritos a base para a formação do indivíduo e das instituições sociais.

Partindo desta centralidade da Torá, a formação do indivíduo judeu passava, primordialmente, pelo aprendizado da tradição oral. Segundo a tradição, a lei oral constituía uma ampliação da lei escrita, ou seja, a interpretação das leis escritas, que tiveram origem no Sinai com as tábuas da lei, isso se fazia necessário para a confrontação com todas as situações vividas pelo povo e a organização social. Desta forma, a organização social e a formação do indivíduo não estavam engessadas em uma tradição de leis escritas, distanciadas das alterações sociais, culturais e políticas do povo. A Torá se constitui numa referência que guia a construção do corpo legislativo do povo judeu e de suas interações sociais internas e externas. Como comenta Schimmel:

$$
\begin{aligned}
& \text { O povo judeu é frequentemente chamado de "O povo do livro", } \\
& \text { mas se alguém procurar um povo que siga literalmente o } \\
& \text { comando da bíblia, pode ser levado aos Samaritanos, os quais } \\
& \text { no entanto, praticam sua religião nos arrabaldes de Schechem, } \\
& \text { ou os Karaitas, os quais estão agora estabelecidos no sul da } \\
& \text { moderna Tel-Aviv, mas nunca o povo judeu. Eles não seguem } \\
& \text { agora a palavra literal da bíblia, nem nunca fizeram isso. Eles } \\
& \text { têm sido moldados e regulados pela interpretação verbal da } \\
& \text { palavra escrita, mais particularmente pela 'Torah', a qual } \\
& \text { abarcar ambas, a lei escrita e a oral. (SCHIMMEL, 1973, p. 19) }
\end{aligned}
$$

Além desta tradição escrita e oral de transmissão das leis e dos costumes, a tradição de manutenção da história dos grandes líderes políticos e religiosos também é muito importante para a identidade do povo judeu. Os livros históricos, que estão logo após o Pentateuco, são a marca viva da ação do povo judeu sob a égide divina. Estes livros, tais como Josué, Juízes, Reis e Samuel, são a saga do povo de Israel e de seus líderes em busca do estabelecimento de um poderio que culminaria no reinado de Davi e Salomão. Desde a saída do Egito, passando pela busca da terra prometida, a luta contra os povos que ali habitavam, a constituição de uma monarquia na figura do rei Saul e a conquista da estabilidade territorial e política com o rei Davi, diversas batalhas e conquistas expansionistas são narradas e passam a ser transmitidas pela tradição oral.

A marca destes livros históricos é a ação de Yahvé como um Deus conquistador, a promessa feita ao povo era a de possuir uma grande nação e um grande poderio territorial. Sendo assim, estes livros históricos mostram esta expansão do povo judeu, de uma multidão fugida da escravidão a uma 
nação poderosa e rica. Destacam-se neste processo os grandes homens 'ungidos' por Deus, um dos maiores exemplos é Davi, de simples pastor de ovelhas a rei de Israel. Certamente que a única preocupação dos textos históricos não era necessariamente ressaltar os valores éticos e morais dos grandes homens que agiram sob a vontade de Deus, a questão que se põe é o estabelecimento de exemplos que demonstrem o poderio de Yahvé ao se valer de homens imperfeitos para execução de suas obras.

Este fator de estabelecimento de exemplos à serem seguidos é fundamental para a formação da cultura judaica e para a formação dos indivíduos. As imagens dos grandes líderes são reverenciadas e dispostas como marcos de ação dentro do contexto social, bem como todas as ações empreendidas em prol da grandeza de Israel e da demonstração da ação divina. A questão das tradições oral e escrita, da história de Israel, é latente no processo de valorização da história do povo desde sua origem. "Israel foi a primeira nação civil a produzir uma historiografia, na época davidicosalomônica, que merece este nome e possa, por fim, reivindicar para si um grau de primazia." (HERRMANN, 1977, p. 57).

Apesar de toda a majestade do reinado de Davi, não é ele a figura central da tradição judaica, pode-se afirmar que a figura mais importante na tradição do judaísmo é a de Abraão, seguido depois por Moisés. Estes dois homens são responsáveis pelo estabelecimento e fortalecimento do povo judeu enquanto povo escolhido. À Abraão foi dada a promessa de ser pai de uma grande nação, ele é o fundador da religião judaica e o pai dos judeus, não Moisés, a este coube a tarefa de resgatar o povo da escravidão e lhe dar corpo político e legislativo enquanto nação. Neste sentido, Moisés é o fundador da nação judaica, enquanto Abraão é o pai do povo judeu e o fundador da religião judaica.

Como nos relata novamente Campos:

Há na história primitiva dos Hebreus, uma anomalia que não tem merecido a atenção e um cuidadoso exame por parte dos estudiosos do Judaísmo. O povo tem a sua origem em Abraão. Yahvé elegeu Abraão, revelou-lhe em primeira mão, tirou-o da sua pátria, da casa dos pais, para o conduzir a um país dele desconhecido. É com Abraão que Yahvé faz o pacto primitivo, pelo qual o deus lhe daria à descendência Canãa, por isso chamada "Terra Prometida", enquanto o profeta se empenhava a uma eterna fidelidade. Daí vem o apelido "Deus da Aliança" com que se conhece Yahvé. Apesar disso tudo, há uma nova revelação, um novo ajuste, um código novo no Sinai, entre Yahvé e Moisés. Afinal, qual dos dois fundou a nacionalidade, Abraão ou Moisés, qual deles iniciou o culto de Yahvé, quem planejou a conquista de Canãa, quem foi o primeiro hebreu a arregimentar os de sua casta numa anfictionia e dar-lhes um código particular? A fórmula clássica até hoje, reza: 'Yahvé, deus de Abraão, Isaque e Jacó', e não 'deus de Moisés'. (CAMPOS, 1961, p. 104). 
Com Abraão foi feito uma aliança, uma promessa que Deus se empenharia em cumprir, com Moisés Deus faz um pacto, o qual deveria ser honrado pelo povo. O papel de Moisés é central porque é ele quem dá ao povo judeu um estatuto político, legislativo e de legitimação de seus costumes, ou seja, o estabelecimento das bases que constituem um corpo social. Além disso, em Moisés se inicia a tradição de um aspecto muito importante do caráter do Deus de Israel, a denominação de "Deus dos Exércitos". É o que nos indica Weber:

\begin{abstract}
No entanto, é extremamente importante sobre o plano prático que, apesar de tais atributos, Yahvé torna-se e permanece a ser, ao menos para o Israel antigo, um Deus da organização social, mesmo que ainda em uma acepção particular. Devemos admitir que desde Moisés ele é o Deus da Aliança da confederação israelita e, conforme o objetivo desta última, essencialmente o Deus dos exércitos. (WEBER, 1970, p. 184).
\end{abstract}

Estes pontos são extremamente importantes para se estabelecer o caráter da religião durante este período de formação da nação de Israel. O sentimento de povo guerreiro e expansionista será o mote dos livros históricos que relatam a saga da ascensão do reino de Israel e sua culminação nas figuras de Davi e Salomão, como já indicamos. A preocupação obsessiva dos judeus em se manterem distante dos povos circunvizinhos e de ressaltar sua eleição exclusiva como povo de Deus, o único e verdadeiro deus, fez com que a aceitação de estrangeiros e o casamento de judeus, e judias, com estrangeiros fossem restritos. Obviamente que isto fez fortalecer o caráter estabilizador das leis estabelecidas pela tradição escrita e oral. No entanto, fez também com que o povo judeu ficasse restrito ao desenvolvimento das doze tribos originais, ou melhor, dos seus representantes que saíram do cativeiro egípcio.

No entanto, o período expansionista e de fulgor do povo de Israel terá fim a partir da ascensão de grandes impérios no Oriente Médio, povos como os babilônios, os assírios, os persas, trouxeram um jugo pesado sobre a nação israelita. Após a derrocada do reinado de Salomão e o cativeiro babilônico, a promessa de um messias restaurador se torna o mote central das profecias. Além disso, a imagem do "Deus dos Exércitos" passará a se tornar mais desbotada e dará lugar à imagem de Deus punitivo, que puni seu povo por não honrar o pacto feito com Moisés. Neste sentido, a ideia de retorno ao princípio fundador da nação, ou seja, o pacto sinaítico com Moisés através da lei e todo o seu ensinamento, será o norte pelo qual a religião judaica se direcionará. Mas, apesar deste esforço, os tempos de conquista e expansão não voltaram pelas mãos de um messias, ao contrário, a religião judaica teve que assimilar os acontecimentos que viriam.

No tópico seguinte nos deteremos na assimilação do judaísmo helenístico pela intelectualidade europeia renascentista, principalmente no 
período no qual Maquiavel está escrevendo. Isto nos permitirá compreender a leitura que se fazia do judaísmo na Europa e a maneira como o judaísmo antigo era obliterado em vista do judaísmo helenístico.

\section{O judaísmo helenístico}

No início do tópico anterior já adiantamos um pouco do que foi o processo de fortalecimento de um judaísmo influenciado, e influenciador, da cultura grega. A preocupação dos judeus em manter sua distinção em relação ao demais povos foi posta à prova quando o mundo civilizado da época se agigantou pelas mãos dos gregos e depois dos romanos. A ascensão destas duas grandes civilizações mudou por completo o quadro geopolítico do Mediterrâneo antigo. Segundo a opinião de Bevan:

Sobre todas as terras ao redor do Leste do Mediterrâneo os
gregos, nos dias de Alexandre, espalharam sua dominação
cultural; então Roma surge em cena, adotando a tradição grega
na literatura, no pensamento e na ciência, somando a ela seu
próprio gênio de governo e leis, então que uma cultura meio
helênica veio impor-se sobre o Oeste Latino, e sob esta dubla
predominância greco-romana todas as outras tradições do
Mediterrâneo perderam prestígio e poder. (BEVAN, 1927, p.
30)

A tradição judaica se mantinha viva nos rituais religiosos e no estudo e transmissão da Torá. No entanto, o processo de dispersão de grande parte do povo judeu da Palestina, fez com que surgissem novas leituras e práticas em relação a esta tradição. Como já apontado anteriormente, a perda do referencial de adoração, o templo de Salomão, a perda do controle da cidade santa de Jerusalém e o surgimento de uma nova religião no seio judaico, fizeram com que as bases político-religiosas fossem abaladas e sofressem influências. Este é o resumo do cenário que se tornou o pano de fundo para o fortalecimento do judaísmo helenístico no início do primeiro século da era cristã. Pode-se intuir que o judaísmo fosse, neste cenário desfavorável do início da era cristã, uma tradição em vias de se extinguir, como fora mais tarde o caso das religiões pagãs grega e romana. Apesar disso, o forte sentimento nacionalista incutido nos preceitos religiosos fizeram com que o judaísmo se mantivesse vivo nos preceitos da tradição. No entanto, é óbvia a mudança do contexto político, as promessas de retomada da independência territorial e política pareciam, certamente, ainda mais distantes do quê no final do século I a.C.

A tradição judaica que se fortaleceu no mundo grego foi direcionada principalmente pelos vetores místicos presentes no judaísmo antigo, bem como seus aspectos sapienciais e ritualísticos. Este movimento é preponderante para a assimilação de aspectos destacados na tradição grega, o que obviamente culmina em escritos mais próximos dos escritos 
ocidentais. A própria tradução da Torá, ou mais centralmente do Pentateuco, para o grego, foi a base para a posterior organização da bíblia cristã organizada sob o império romano. De acordo com Renckens:

Assim o targum do Pentateuco que se nos conservou é uma fonte natural para a crítica do texto e sobretudo para a história mais antiga da exegese. Mais para o Oeste e sobretudo no Egito, o aramaico foi, desde Alexandre, desalojado como língua universal pelo grego. Nas sinagogas helênicas seguia, portanto, após a leitura hebraica, uma paráfrase grega. Hoje em dia todos concordam em que a própria Septuaginta ou ao menos a sua base deve ser considerada como um targum grego. (RENCKENS, 1969, p. 244).

A valorização dos aspectos místicos do judaísmo em uma vertente helenística não é interessante apenas pelo fato de demonstrar o sincretismo e assimilação que se possa existir entre as duas tradições. Na verdade, o que se impõe é uma forma de pensar e viver a religião em um âmbito sociopolítico. A ênfase do "Deus dos Exércitos" já está no passado, a expectativa por um messias político, guerreiro e conquistador também já está em descrédito. A própria tradição de formação do indivíduo judeu e da valorização dos exemplos à serem seguidos é distinta daquela que configurava o judaísmo antigo. A ampliação de uma abordagem mística do judaísmo traz consigo uma maneira de viver a religião que se desprende do contexto político, ou seja, o judeu vive sua religião no âmbito privado de sua casa e nos aspectos introspectivos que ela traz. Estes são os traços de todas as religiões pautadas em aspectos místicos despregados do contexto político. Para Scholem:

\footnotetext{
A mística hebraica, nos seus diversos aspectos, representa a tentativa de entender como valores místicos e valores religiosos típicos do hebraísmo; ela se concentra na representação do Deus vivente - que se manifesta na criação, na revelação, na redenção - desprendendo-se ao ponto de fazer surgir deste domínio do Deus vivente todo um mundo de vida divina, no qual o segredo é ativo e presente em cada ser. (SCHOLEM, 1993, p. 23).
}

O próprio cristianismo é uma religião fortemente arraigada em aspectos místicos que permitem ao indivíduo vivenciar sua religião independentemente do âmbito social que o envolve. Não apenas o caráter de coesão social do judaísmo se modifica na tradição helenística, a própria construção da identidade legislativa do povo judeu sofre interferência direta. Viver em Jerusalém sob um forte código legislativo-religioso é uma coisa, mas, viver em terras estrangeiras, sob um código legislativo que não se baseia em uma tradição própria, é outra bem diferente. 
As tradições da lei escrita e da lei oral são brutalmente atacadas no sentido de se adequarem, em um contexto político distinto no qual a religião perde seu poder de coesão e no qual os aspectos místicos são predominantemente despregados do viver social. A tradição sapiencial dos comentadores e sábios passará a preencher a lacuna deixada pela ausência de poder de coesão por parte das tradições da lei. Ou seja, um processo de adequação do milenar código judaico é forçosamente posto em marcha no período helênico. A tradição será interpretada, condicionada, adequada as realidades impostas por condições políticas, econômicas e sociais. Esta será uma marca do judaísmo helenístico, o processo de interpretação das leis, tendo como principal discussão a manutenção de sua identidade principal, sua origem na vontade divina. Como comenta Schimmel:

\begin{abstract}
A vontade de Deus como expressa pelas leis sinaíticas foi absolutamente mantida nos Sábios. 'Têm, então, os Sábios poder para sobrepor esta lei da Torah?', o Sábio perguntou. Até então, em circunstâncias excepcionais, a Torah empodera os Sábios a legislarem contrariamente à lei sinaítica. Exatamente o que essas circunstâncias são é uma matéria de disputa entre os primeiros grandes estudiosos. (SCHIMMEL, 1973, p. 109).
\end{abstract}

Pode-se afirmar que o povo judeu, onde quer que esteja, fora de Jerusalém, tem dois códigos de lei, um do Estado onde esteja, outro da Torá e da tradição. Sendo assim, o processo de helenização do judaísmo foi também o processo de quebra com a tradição da lei, bem como o processo de quebra do papel da religião judaica como argamassa de formação de uma identidade territorial. Em detrimento a isto, este processo de helenização da tradição judaica foi o trampolim para sua inserção no mundo civilizado de então. O mundo grego, posteriormente herdado pela cultura romana, estabeleceu as vigas da civilização ocidental, principalmente os alicerces políticos e intelectuais que a formaram.

Neste sentido, devemos entender que o judaísmo conhecido pelos europeus medievais e renascentistas é aquele da tradição helenística e posteriormente cristã. Muito pouco se conhecia das tradições que se mantiveram fiéis aos traços presentes no judaísmo antigo, ou veterotestamentário. $\mathrm{O}$ próprio cristianismo católico, até o acontecimento da reforma protestante, se manteve próximo do chamado Cânone de Alexandria, que possuía seis livros a mais(os chamados livros sapienciais) do que do Cânone de Jerusalém, que se mantinha fiel ao formato da Torá. Lutero retomará o Cânone de Jerusalém, dizendo ser necessário voltar à origem, por isso a bíblia utilizada pelos protestantes tem seis livros a menos que a bíblia utilizada pelos católicos romanos.

É interessante entender como o judaísmo era visto pela Europa cristã, ou seja, para a Cristandade o velho testamento, bem como o judaísmo contido nele, é apenas um prenúncio da verdadeira religião, a cristã. Por 
conta disto, a tradição sapiencial do judaísmo helenístico será assimilada como um movimento intelectualmente distinto da tradição cristã, bem como daquele judaísmo expresso no velho testamento. No entanto, os entrelaçamentos entre judaísmo, cristianismo e filosofia se tornaram cada vez mais próximos, ao ponto de se desenvolverem correlatamente, como correntes essencialmente próximas. Esse movimento se espalhava por toda a Europa no período medieval, da Espanha à Alemanha, com algumas distinções nesta última. Como argumenta Scholem:

\begin{abstract}
No medievo o mundo hebraico-alemão se tem distanciado dos problemas teológicos e filosóficos, que ao invés, naquele tempo, agitavam profundamente as comunidades oriental, espanhola e italiana, promovendo nestes grupos um desenvolvimento decisivo. Seja a introdução de novos valores e ideias na concepção de Deus na antropologia e na ética por parte dos teólogos e filósofos hebreus, os sucessivos desenvolvimentos - que se poderiam descrever como a luta entre Platão e Aristóteles pela hereditariedade bíblica e talmúdica do hebraísmo - tudo isso interessou bem pouco à comunidade hebraica da Alemanha e do norte da França, e teve sobre elas pouca influência. (SCHOLEM, 1993, p. 95)
\end{abstract}

Temos então, na Idade Média e no Renascimento, basicamente duas tradições judaicas conhecidas e assimiladas, a primeira, aquela do judaísmo helenístico, mais destacada pela mística e pela proximidade com a tradição filosófica grega, a segunda, aquela da tradição judaica atrelada à história do cristianismo na figura do cristo, que se confundia com a própria religião cristã e era suprassumida por essa. "O número dos temas proféticos postos em relação com a vida de Cristo e a infidelidade de Israel justifica igualmente o recurso frequente aos profetas principais." (DAHAN, 2007, p. 389). O judaísmo antigo, com toda a sua significação política, social e religiosa, já estava totalmente restrito a comunidades que mantiveram a tradição da Torá, principalmente aquelas que não se afastaram de Jerusalém após a diáspora.

Na Itália renascentista, como já aludimos acima, estavam presentes as duas principais tradições judaicas mais conhecidas pelos europeus, de um lado, por uma vertente atrelada à filosofia neoplatônica, a mística judaica, por outro lado, atrelada a leitura cristã do judaísmo, a tradição judaicocristã. Ambas as tradições estavam distanciadas daquela tradição antiga do judaísmo, sendo assim, os próprios aspectos político-religiosos contidos nesta última também estavam obliterados. A mística judaica, tangenciada por correntes esotéricas, neoplatônicas e sapienciais, se expressava principalmente nos círculos filosóficos e astrológicos. A Kabbala havia ganhado força neste movimento e tinha se tornado uma fonte de inspiração mística e esotérica, um fenômeno surgido no seio judaico da Cristandade. Scholem novamente comenta: 
De início se põe muito naturalmente duas questões: em quais circunstâncias a Kabbala tem aparecido na cena histórica, e quais eram as características da época em que a vimos surgir? É certo que como fenômeno histórico no judaísmo medieval, a Kabbala nasceu na Provença, mais exatamente em sua parte ocidental, no Languedoc. De lá, ela foi transplantada, no primeiro quarto do século XIII, em Aragão e Castella, onde ela tornou-se conhecida pela sequência de seu desenvolvimento clássico. Ela constitui-se por tanto numa manifestação da vida judaica no Ocidente cristão, e não possuímos nenhuma informação histórica, nenhum documento direto sobre sua existência ou sua propagação nos países do Islã. (SCHOLEM, 1966, p. 20-21).

O Renascimento italiano está aberto a ambas as tradições, uma advinda de sua vertente místico-filosófica e aquela leitura cristã do judaísmo contido no velho testamento e suprassumido pela imagem do Cristo. Esta mista presença judaica nos escritos renascentistas pode ser bem entendida a partir das obras de autores como de Pico della Mirandola. Este autor é notadamente conhecedor e estudioso das diversas vertentes místicas e sapienciais de origem grega, hebraica e árabe. Sua principal obra sobre a condição do homem como ser livre e de ação é sem dúvidas o Discurso ${ }^{4}$. Vejamos, a partir de suas palavras, a condição das ações do homem:

Portanto, ainda que dedicados à vida ativa, se assumirmos tratar as coisas inferiores com reto discernimento, afirmar-nosemos com a firmeza dos tronos. Se libertos das ações, meditando na criação o artífice e no artífice a criação, estaremos imersos na paz da contemplação, resplandeceremos rodeados de querubínica luz. [...] Sobre o trono, isto é, acima do justo juíz, está Deus juíz dos séculos. (PICO DELLA MIRANDOLA, 1942, p. 271.)

Sua visão sobre a natureza humana se pauta pela liberdade, estritamente humana, de se degradar ou se elevar em termos quase divinos, ou seja, a liberdade de alçar um movimento de aprimoramento intelectual e espiritual. No tocante a esta liberdade, e pesando aí o antagonismo entre coisas inferiores e coisas superiores, a contemplação se firma como caminho seguro para tal aprimoramento. As leis refletem também este processo que se deve constituir como ascendente, o justo juiz se ilumina sob os auspícios do juiz dos séculos. "O texto 'pichiano', decantado a dignidade e a liberdade do homem, exalta a sua possibilidade de desvencilhar-se das cadeias

4 Em muitas edições a obra se intitula 'Discurso sobre a dignidade do homem', porém, como muitos estudiosos têm observado, este título propriamente pertence somente à primeira parte do discurso. O título original da obra era simplesmente 'Discurso'. KRISTELLER, Paul O. Ocho filósofos del renacimiento italiano. Traducción de María Martínez Peñaloza. Madrid: Fondo de Cultura Económica, 1996. Pág. 91. 
perversas dos pecados e sair em direção a Deus, continuando e aprofundando assim o curso do pensamento medieval escolástico." (GUKOUSKJ, 1965, p. 462).

Mas do que ser um ponto de convergência entre as doutrinas e tradições místicas, judaica e árabe, com o ensino essencialmente cristão e as doutrinas filosóficas, Pico é a imagem icônica do que foi o processo de apreensão das tradições orientais na intelectualidade ocidental, principalmente no Medievo e no Renascimento. Certamente que não pretendemos aprofundar este quadro, no entanto, nos interessa demonstrar como a tradição do judaísmo antigo já estava obliterada no contexto intelectual europeu no fim do Medievo. Interessa-nos também apontar que é neste cenário que Maquiavel tomará conhecimento das figuras históricas do judaísmo, principalmente Moisés.

Neste sentido, no próximo tópico, buscaremos demonstrar como a descrição maquiaveliana do papel da religião na organização político-social de uma nação pode se coadunar a alguns dos aspectos principais do judaísmo antigo e pode ser utilizada para compreender esta religião em um patamar mais próximo das religiões pagãs antigas do que do cristianismo.

\section{O judaísmo antigo a luz da visão maquiaveliana de religião}

O assunto da religião nos escritos maquiavelianos é permeado de inúmeras alusões às religiões pagãs, dos povos itálicos do período de ascensão dos romanos enquanto poderio regional, bem como, e em maior grau, dos próprios romanos. Porém, em alguns momentos Maquiavel faz menção à ícones de outras culturas, principalmente das tradições mitológico-religiosas grega e judaica. Temos como exemplos Teseu e Moisés, principalmente quando o tema é a fundação e a organização político-legislativa de uma nação. No entanto, refletindo o que era a apreensão do judaísmo em seu tempo, Maquiavel não aprofunda os aspectos religiosos e históricos do povo judeu.

Como já indicamos na introdução deste trabalho, nos dedicaremos a prescrutar uma identificação destes aspectos religiosos do judaísmo antigo com as descrições feitas por Maquiavel a respeito do papel da religião na organização, estabilidade e expansão de um Estado. Certamente que este movimento trará atrelado à si a necessidade de recorrermos aos textos históricos do velho testamento, bem como aos textos maquiavelianos, principalmente os "Discorsi". No entanto, antes de fazer esta aproximação, entre os textos históricos do judaísmo antigo e a leitura maquiaveliana do papel da religião, precisamos pontuar rapidamente a questão da história nos escritos do Florentino.

Diante da utilização, por parte de Maquiavel, de figuras da mitologia grega, romana e da tradição judaica expressa pela leitura cristã, surge o problema de se especificar se o autor aceita estes relatos como realmente 
históricos ou se ele os toma apenas como modo de ilustrar suas asserções. Mais ainda, se o autor, retomando tais histórias como exemplificação, acredita que se possa reproduzir os atos expressos nos relatos aludidos. Para Maquiavel as paixões dos homens não conhecem limites temporais ou culturais, em todos os tempos e em todos os lugares os homens tiveram e terão sempre as mesmas paixões e inquietações. Em suas palavras:

Aquele que estuda a história atual e a antiga verá que os mesmos desejos e as mesmas inclinações reinaram e reinam em todos os governos, bem como em todos os povos. Por isto é fácil, ao que estuda com cuidado os acontecimentos passados, prever o que o futuro reserva a cada governo, propondo os remédios já utilizados pelos antigos ou, caso isto não seja possível, imaginando novos remédios, baseados na similaridade dos ocorridos. (D. I, 39. MACHIAVELLI, 1997, p. 282).

Por este prisma, entende-se que Maquiavel não está centrado nem na veracidade histórica dos fatos narrados, nem na simples exemplificação de verdades morais ou políticas através de tais fatos. Seu foco é compreender a ação humana no contexto político e a partir daí pensar a realidade política de seu próprio tempo. Ou seja, a peça central da história continua sempre a mesma, o indivíduo humano. Este indivíduo tem uma natureza inalterada, propensa sempre aos mesmos fins. "O paralelismo entre as leis da natureza e as leis da história dão a esta última uma solidez e uma força suplementar.'(D’ISTRIA/FRAPET, 1980, p. 35). Sendo assim, prescrutar a história não é apenas buscar a veracidade dos fatos, é antes entender como as paixões, os desejos, as inclinações da natureza humana moldam sua vida social e política e como isso pode ser usado como aprendizado para compreender seu próprio tempo.

Os relatos históricos dos judeus contidos no velho testamento seriam então, nesta perspectiva maquiaveliana, uma fonte de compreensão das consequências das ações humanas, em vista de suas paixões e inclinações, no seio daquele determinado povo e cultura em um determinado tempo. Certamente que esta compreensão pode ser usada para o entendimento de seu próprio tempo, seja na formulação de respostas políticas aos problemas sociais, seja na formulação de teses sobre as consequências das ações do homem de modo geral.

Não podemos ainda deixar de lado o fato de que Maquiavel é um indivíduo vivendo em uma sociedade cristã, altamente punitiva no tocante a tudo aquilo que contradiga os dogmas aceitos. Porém, mais do que a coerção pela punição, tal sociedade cria em torno de si uma narrativa social que permeia e ao mesmo tempo reflete as crenças e percepções desses mesmos dogmas. Como já demonstramos no tópico anterior, a tradição judaica que se conhece mais amplamente na Europa de Maquiavel é aquela suprassumida pela realidade do Cristo, principalmente em sua definição 
como messias. É interessante ver no capítulo 26 de "O Príncipe", um tom quase messiânico de exortação àquele que há de vir salvar a Itália de seus inimigos. Como segue:

\begin{abstract}
E se, como eu disse, era necessário, querendo ver a virtù de Moisés, que o povo de Israel fosse escravo no Egito; e a conhecer a grandeza de ânimo de Ciro, que os persas fossem oprimidos pelos medos; e a excelência de Teseu, que os atenienses fossem dispersos; assim no presente, querendo conhecer a virtù de um espírito italiano, era necessário que a Itália se reduzisse aos termos presentes e que fosse mais escrava que os hebreus, mais serva que os persas, mais dispersa que os atenienses: sem líder, sem ordem, batida, espoliada, lacerada, saqueada e tenha suportado todo tipo de ruína. Embora até aqui, se tenha visto em alguns, certos lampejo de esperança, podendo julgar que fosse ordenado por Deus para sua redenção, também se viu como depois, no mais alto curso de suas ações, foram pela fortuna reprovados. (P. XXVI. MACHIAVELLI, 1997, p. 189 - 190).
\end{abstract}

Entendemos que Maquiavel tem um conhecimento limitado da história do povo judeu, a partir da leitura cristã de sua época e das assimilações que ela sofreu na cultura ocidental, como já demonstramos. Sendo assim, não buscaremos nos textos maquiavelianos referências que indiquem um profundo conhecimento do judaísmo antigo, no entanto, num movimento de contraluz, tomaremos as indicações maquiavelianas do papel da religião no corpo social e buscaremos, na história e na tradição do judaísmo antigo, veterotestamentária, paralelos que possam ser validos. Esse movimento deve ser guiado por duas questões muito próximas no pensamento do Florentino, primeiro, a formação do indivíduo em uma tradição religiosa que permita uma ordenação social e defesa da pátria, segundo, um uso da religião que permita o fortalecimento do espírito de luta dos exércitos e o medo em infringir as regras sociais estabelecidas nas leis.

Sua crítica ao cristianismo é muito bem conhecida por aqueles que se dedicam a este tema da religião, o principal momento desta crítica parece ser a acusação de que o cristianismo tende a criar homens submissos, mais amantes da contemplação do que dos grandes atos de coragem e força. Nas palavras do Florentino:

Pensando, portanto, donde possa nascer, que, naqueles tempos antigos, os povos fossem mais amantes da liberdade que neste; creio nasça daquela mesma causa que faz agora os homens menos fortes: a qual creio seja a diversidade da nossa educação em relação à antiga. Porque, havendo a nossa religião mostrado a verdade e o verdadeiro caminho, se faz estimar menos a honra mundana: onde o gentios, estimando-a bastante, e havendo posto nisso o sumo bem, eram em suas ações mais ferozes. [...]. A nossa religião tem glorificado mais os homens 
humildes e contemplativos, que os ativos. Tendo ainda posto o sumo bem na humildade, abnegação e no desprezo das coisas humanas; enquanto a outra o colocou na grandeza de ânimo, na fortaleza do corpo, e em todas as outras coisas capazes de fazer o homem fortíssimo. (D. II, 2. MACHIAVELLI, 1997, p. 333.)

Esta dura crítica lançada sobre a educação advinda de uma compreensão cristã do mundo demonstra a preocupação de Maquiavel em relação à formação dos indivíduos. "Maquiavel prefere uma humildade diferente da professada pelos cristãos e um orgulho diferente do qual eles inadvertidamente caem. Ele assume que o homem deve lutar por si mesmo, reconhecer esta necessidade é o tipo de humildade que pode tornar homens em soldados.”(SULLIVAN, 1996, p. 50). Sua intenção não é a de defender um retorno ao paganismo romano ou antigo, no entanto, sua crítica está voltada para a valorização de algo que não está em consonância à defesa da pátria e ao bem comum do corpo político. Ou seja, independente da pretensa verdade do conteúdo religioso ou de seus meios para a purificação moral ou espiritual dos indivíduos, o principal papel da religião é contribuir para a formação de indivíduos comprometidos com a defesa, o ordenamento e o crescimento do Estado. Neste sentido, podemos procurar no judaísmo antigo este direcionamento da religião indicado por Maquiavel, principalmente no tocante à defesa e expansão da pátria e o amor à liberdade.

No judaísmo antigo a educação do indivíduo, através dos textos históricos e da Torá, era guiada pela clara intenção de se incutir a imagem de Yahvé como o "Deus dos Exércitos", tanto a necessidade de defesa quanto a necessidade de expansão e estabilidade territorial levavam a este direcionamento. Como aponta Liverani:

O paradigma adotado no livro de Josué é aquele da 'guerra santa', de clara matriz deuteronomista, mas dotada de profunda raiz na ideologia siro-palestina após séculos da pressão assíria. A historiografia deuteronomista o aplicou retrospectivamente a toda a história das relações entre Israel e os outros povos, não só pela época da conquista, mas antes pela época dos Juízes e depois pela primeira idade monárquica. Os princípios fundamentais da guerra santa são os seguintes: Deus é conosco, combate ao nosso lado e garante a vitória; os inimigos, mesmo que aparentemente mais fortes, não podem prevalecer diante de tal apoio, são destinados a derrota; as ações bélicas vão, porém, precedidas de adequada preparação votiva-cultual, cada erro ou negligência neste sentido será punido com o insucesso; o fruto da vitória será votado a Deus (o qual é o artífice) e portanto será ritualmente destruído sem trazer vantagem material. (LIVERANI, 2006, p. 315).

Este espírito de combate em nome de Deus é fartamente descrito no Pentateuco, principalmente nos livros que tratam da expansão do povo saído do cativeiro e no seu estabelecimento diante dos diversos povos que 
habitavam a terra de Canaã. $\mathrm{O}$ amor à pátria, Israel, é o próprio amor a Deus, ou seja, um sentimento está intrinsecamente atrelado ao outro. "Fica claro, pela leitura do antigo testamento, que a guerra não era um problema para os antigos israelitas."(HOBBS, 1997, p. 16). A vontade de Deus é expressa na ação dos indivíduos que agem em prol do crescimento do reino de seu povo, em geral, tal crescimento só é conquistado por meio de lutas sangrentas e destruições dizimadoras.

Moisés é a principal figura na educação beligerante do povo, ele traz a mensagem expansionista de Deus:

\begin{abstract}
Moisés disse ao povo:
- O Senhor, nosso Deus, fará com que vocês entrem na terra que vão possuir e ele mesmo expulsará os povos que vocês enfrentarem. Conforme vocês forem avançando, Deus derrotará sete povos que são mais numerosos e mais poderosos do que vocês. São eles: os heteus, os girgaseus, os amorreus, os cananeus, os perizeus, os heveus e os jebuseus. O senhor entregará esses povos nas suas mãos, e vocês os atacarão e destruirão completamente. Não façam nenhum acordo de paz com eles, nem tenham pena deles. (Deuteronômio 7: 1,2).
\end{abstract}

Este caráter de nação conquistadora é enfatizada na tradição do judaísmo antigo como sinal da presença de Deus, é um claro uso do poder de convencimento da religião no processo de adesão do povo à luta pela expansão da pátria e sua defesa. Isso se reflete também na descrição das ações dos grandes líderes, principalmente em momentos de disputa territorial ou de poderio local. A valorização da ação contundente, direcionada para o fortalecimento da nação, é o mote central das narrativas contidas nos livros históricos. Em geral, tais narrativas são demonstrações de ferocidade e força, ordens dadas pelo próprio Deus e levadas a cabo sem nenhum tipo de piedade. Contrariar tais ordens é ir contra a vontade do próprio "Deus dos Exércitos", mais ainda, é colocar em risco a própria soberania e liberdade da nação. Isso pode ser ilustrado pelo caso do rei Saul, este foi eleito por Deus como rei de Israel, recebeu a ordem de exterminar todo ser vivo nas cidades vizinhas a região destinada ao povo de Deus, no entanto, ele não cumpriu tal ordem. Como está relatado no livro de Samuel:

Samuel disse à Saul:

- O senhor Deus mandou ungir você para ser rei de Israel, o povo dele. Agora escute isto que o Senhor Todo-Poderoso diz. Ele castigará os amalequitas porque eles lutaram contra os israelitas quando estes vieram do Egito. Vá, ataque os amalequitas e destrua completamente tudo o que eles têm. Não tenha dó nem piedade. Mate todos os homens e mulheres, crianças e bebês, gado e ovelhas, camelos e jumentos. [...] - Eu pequei, respondeu Saul, desobedeci as ordens de Deus, o Senhor, e as instruções que você deu. Fiquei com medo do povo e fiz o que eles queriam. Mas agora, Samuel, eu peço que 
perdoe o meu pecado e volte comigo para que eu possa adorar o senhor. - Eu não voltarei com você! Respondeu Samuel. Você rejeito as ordens de Deus, o Senhor, e por isso ele também o rejeitou como rei de Israel. (1 Samuel 15: 1- 3; 24 26).

Esta narrativa presente no livro de Samuel retrata bem o que era a relação entre a religião e a política no judaísmo antigo. Ao dar a ordem de Deus, Samuel estava fortalecendo na mente do povo a ideia do comando divino de todos os atos de guerra e a legitimação de todas as leis que regulavam a sociedade israelita. Saul, como rei de Israel, não poderia contradizer tal ordem, pois, fazendo isso, colocava em risco todo o arranjo político-religioso que impulsionava a educação do povo e o ordenamento social. É clara a crueldade e ferocidade da ordem divina, todos os seres vivos pertencente ao povo inimigo deveriam ser mortos. No entanto, Saul descumpre a ordem, deixa vivo o rei inimigo, Agague, e todos os bons animais que os pertenciam. Isto não é apenas um descumprimento de uma ordem divina, é a quebra de um processo de ordenamento social, a legitimação das leis e o próprio ordenamento das instituições sociais dependiam de uma educação baseada em princípios claros.

Este fator de manutenção de uma clara ordenação das instituições sociais é muita cara à Maquiavel, segundo ele, toda a manutenção das leis, a ordenação das relações sociais e a legitimação política depende disso. A religião tem um papel importantíssimo nisso, seja incutindo uma educação que leve o indivíduo a respeitar as leis, seja impondo rituais e práticas que despertem o temor e o respeito na mente das pessoas. Como argumenta o Florentino:

\footnotetext{
Quando se examina o espírito da história romana, é forçoso reconhecer que a religião servia para comandar os exércitos, levar a concórdia ao povo, zelar pela segurança dos justos e fazer com que os maus corassem pelas suas infâmias. De modo que, se tivesse de dizer a quem Roma devia maiores obrigações, se a Rômulo ou a Numa, creio que este último teria a preferência. (D I, 11. MACHIAVELLI, 1997, p. 229, 230).
}

Pode se dizer que o mesmo se dá no seio da sociedade israelita nos tempos do velho testamento, a ordenação social dependia indelevelmente do respeito e da estrita observância da religião nacional. Saul sendo o líder da nação, o rei escolhido pelo próprio "Deus dos Exércitos" não poderia quebrar esta ordem estabelecida, sendo ela o elo entre as instituições políticas e religiosas. "Os dirigentes de uma república ou de uma monarquia devem respeitar os fundamentos da religião nacional." (D. I, 12. MACHIAVELLI, 1997, p. 232). A consequência desta alteração no ordenamento político-religioso poderia ser um desequilíbrio na própria estabilidade interna do corpo social. Para sanar tal indesejável consequência 
a única ação possível era renovar o temor no coração dos indivíduos e restabelecer os princípios religiosos que davam sustentação às instituições políticas e sociais.

Sendo assim, o que fez Samuel na sequência da narração pode parecer ainda mais cruel e bárbaro, algo próprio das religiões pagãs mais primitivas e que se assemelha bastante ao que era a prática entre os bárbaros na época dos romanos. Como segue:

\author{
E Samuel ordenou: \\ - Tragam aqui o rei Agague. Tremendo de medo, Agague foi \\ até o lugar onde Saul estava e disse: \\ - Como é amargo morrer! \\ Samuel disse: \\ - Assim como a sua espada fez muitas mães ficarem sem filhos, \\ agora também a sua mãe vai ficar sem o seu filho. Em seguida \\ Samuel cortou Agague em pedaços, em Gilgal, em frente do \\ altar. (1 Samuel 15: 28 - 30)
}

Diante de todo o povo, Samuel esquarteja o rei inimigo, Agague, cumprindo o que tinha sido a ordem original do "Deus dos Exércitos". "Dentro desta constituição, o profeta devia desempenhar um papel-chave. Ele colocava os limites ao exercício do poder da parte do rei, e era dever do profeta proteger a aliança divina das violações humanas." (HOBBS, 1997, p. 153). Certamente que é um espetáculo bárbaro e cruel, no entanto, ele tinha a função de restaurar, como dissemos, a estabilidade da ordem político-religiosa. Este fato no livro histórico de Samuel ilustra bem o que era a educação bélica trazida pela religião, mas, além disso, retrata o formato da judaísmo antigo enquanto religião nacional. O sacrifício em si não tinha um ensinamento religioso, não era costume no judaísmo antigo a imolação de um ser humano, no entanto, a necessidade de se manter a ordem estabelecida exigia tal extremo. Até este momento na história da nação de Israel as organizações sociais e políticas estavam intrinsecamente atreladas às disposições da religião, a monarquia só estava começando e sua legitimação ainda carecia de fundamentos mais sólidos, fundamentos estes que só poderiam vir com a própria legitimação advinda da religião.

Maquiavel é enfático ao defender a necessidade de acontecimentos excepcionais que tragam o temor da punição e o respeito às leis, ele está atento a estes acontecimentos na história de Roma e os indica como sendo momentos nos quais a manutenção da estabilidade é garantida, e faltando estes, os homens se tornam corruptos e causadores de tumultos. Vejamos isto em suas palavras:

Entre aquelas execuções antes da tomada de Roma pelos gauleses, foram notáveis a morte dos filhos de Brutos, a morte dos decênviros, aquela de Spúrio Moelio; depois da tomada de Roma, foi a morte de Mânlio Capitolino, a morte do filho de Mânlio Torquato, a execução de Papirio Cursor contra Fábio, 
seu mestre de cavalaria, pela acusação contra os Cipiões. As quais coisas, porque eram excepcionais e notáveis, todas as vezes que ocorriam, faziam os homens retornarem em direção ao princípio fundador; e quando começaram à ser mais raras, começaram a dar mais espaço aos homens de se corromperem, com mais perigo e tumulto. (D I, 1. MACHIAVELLI, 1997, p. 418).

Este processo de "educação pela força" é amplamente utilizada por Maquiavel em seus textos, diversas vezes atrelada à função da religião, principalmente na manutenção da estabilidade política e no incentivo ao combate. No caso de Israel, este espetáculo sangrento era necessário, naquele momento, exatamente para manter, como dissemos, a legitimação do governo monárquico recém-estabelecido. Este modelo de governo, a monarquia, foi estabelecido logo após o período de governo centrado na figura proeminente dos Juízes. "Essa instituição é paralela à instituição monárquica, mas sem comportar o elemento dinástico e a 'aura' religiosa. Uma edição do Livro dos Juízes parece haver utilizado essa noção para elaborar uma história pré-monárquica da salvação da nação... (CAZELLES, 1986, p. 109).

Após a derrocada de Saul como primeiro rei de Israel, vê-se surgir uma das figuras mais importantes do judaísmo, Davi ascende a partir de um acontecimento ímpar. Segundo o relato bíblico, Davi se aproveita de uma situação de desafio feito por um guerreiro inimigo e demonstra extrema bravura e destreza de luta. Certamente que a veracidade do fato pode ser posta em dúvida, mas, no âmbito da tradição judaica antiga, a luta entre Davi e o gigante Golias é um dos pontos altos das conquistas empreendidas no início da monarquia em Israel. Não deixa de ter um fundo simbólico, um garoto com uma arma simples, uma atiradeira, vence um gigante experiente e bem armado. A simbologia da própria ascensão do povo judeu é expressa neste episódio, um povo pequeno que se estabeleceu e conquistou poder sobre povos mais numerosos.

A história de Davi pode ainda ser lida a partir de termos postos por Maquiavel em seus textos, ele se aproveitou de uma oportunidade excepcional, a Fortuna lhe trouxe a possibilidade de demonstrar audácia e coragem, coisas que segundo o Florentino são primordiais para se ter a sua graça. Além disso, demonstrou ainda desprendimento e acabou conquistando a posição de rei, demonstrando Virtù ao ascender como chefe militar e enfraquecendo seu principal rival, o próprio Saul, depois aniquilando seus descendentes. No entanto, as disposições morais de Davi não são seu ponto forte, na verdade, diversos ícones da tradição antiga, expressa no velho testamento, não são exemplos morais. Segundo a avaliação de Campos:

O caráter do rei Davi transparece nas lendas e notícias que, sobre ele, nos dá a bíblia. Foi um homem forte, capitão sábio e 
prudente, capaz de disciplinar e manejar, para o êxito das empresas, a valentia, a audácia e a impulsividade dos seus homens. Impiedoso e feroz para com inimigos que o contrariassem ou pudessem, mesmo remotamente, prejudicarlhe os planos, tolerante e mesmo generoso com os demais. Soube arranjar um pretexto piedoso para mandar empalar perante Yahvé, em sufrágio de Yahvé, os sete filhos sãos de Saul (II Sam. XXI 1 - 14) e poupou o filho de Jônatas, Meribaal, um tolo e pobre aleijado, para que esse comendo à sua mesa, lhe testemunhasse magnanimidade. Inescrupuloso e covarde quanto aos meios de satisfazer os apetites de homem libidinoso e incontinente...(CAMPOS, 1961, p. 138).

No entanto, é interessante notar que Davi só foi repreendido e punido quando cometeu uma ação em benefício próprio. No episódio em que ele toma a mulher de Urias, a engravida e depois planeja a morte de seu marido. Neste momento ele é repreendido por Samuel, no entanto, quando ele mata por empalamento os filhos de Saul, os quais poderiam reclamar o direito de hereditariedade ao trono, ele não foi repreendido. Certamente que esta hereditariedade maldita de Saul estava também rechaçada pelo viés da religião, uma vez que Saul foi rejeitado como rei e condenado pelo principal profeta, Samuel. No entanto, isso demonstra a preocupação de Davi em manter-se seguro na posição de único rei de Israel e poder garantir a estabilidade do reino. Sendo assim, podemos asseverar que a ação de Davi está de acordo com o que indica Maquiavel sobre a justificação do governante diante de atos extremos, quando sua intenção é manter a estabilidade da nação e evitar desordem. Como segue:

\footnotetext{
Desta forma, o bom legislador, animado pelo desejo único de servir não aos seus interesses pessoais, mas os do público: de trabalhar não em favor dos próprios herdeiros, mas para a pátria comum, não fará conta dos esforços para manter em seu poder toda a autoridade. E nenhuma mente esclarecida reprovará quem se tenha valido de uma ação extraordinária para instituir um reino ou uma república. (D. I, 9. MACHIAVELLI, 1997, p. 418).
}

A constituição de uma nação, tendo como ancoradouro uma religião nacional, sem vínculos sincréticos com outros povos é uma tarefa que demanda tempo e um forte sentimento de unidade. No período davídicosalomônico, de certa forma, a constituição da nação Israelita já estava em seu apogeu, saindo de um longo período tribal, dirigida por líderes locais e Juízes. A instituição da monarquia foi de certa maneira uma adequação aos modelos vigentes nas nações vizinhas. Este processo, estabilizado na figura de Davi, foi um marco para o desenvolvimento da nação israelita. "Quando foi introduzida a monarquia em Israel, as armas tornaram-se muito mais numerosas." (HOBBS, 1991, p. 90). 
Apesar deste destaque da figura de Davi, como já aludimos, Moisés é sem dúvidas a personagem mais conhecida da história do povo judeu, principalmente para os não-judeus. Em Maquiavel, a figura de Moisés é posta junto daquela dos grandes legisladores e fundadores de nação, sendo arrolado entre os príncipes que tiveram virtude para se tornarem líderes e aproveitarem a oportunidade que lhes surgiu. Apesar de ser depois, de certa maneira, marcado como executor da estrita vontade divina, como está no livro $\mathrm{V}$ de $O$ Príncipe. A despeito disso, é claro que Maquiavel vê nas ações de Moisés, expressas no antigo testamento, traços políticos, ancorados em preceitos religiosos que merecem ser analisados e até imitados. Como ele mesmo coloca:

\footnotetext{
Para vencer tal tipo de inveja, existe apenas um remédio: a morte. Se a sorte for então propícia a um homem virtuoso que o liberte dos inimigos, dando-lhes morte natural, ele poderá prevalecer sem oposição, usando, sem empecilhos, qualidades que não ofenderão a mais ninguém. Mas, se não tiver esta sorte, será preciso desfazer-se dos rivais por todos os meios, sem poupar esforços, antes de alçar qualquer empreendimento. Se lermos a Bíblia, interpretando-a como é propício e devido, veremos que Moisés, para firmar as leis e as instituições, foi obrigado a matar muitos indivíduos que, levados por inveja, se opunham aos seus desígnios. (D. III, 30. MACHIAVELLI, 1997, p. 572).
}

O Florentino está se referindo à passagem de Êxodo 32, quando Moisés desce do monte Sinai com as tábuas da lei e vê o povo em cultos diversos daquele estabelecido por ele. Na sequência do texto bíblico, Moisés chama os homens que estavam com ele e que temiam à Deus, os da tribo de Levi, e manda que estes matem todos os indivíduos, homens e mulheres, que se rebelaram. Neste episódio mais de três mil pessoas foram mortas. Esta citação específica da ação de Moisés, demonstra que Maquiavel realmente tinha um conhecimento dos textos do antigo testamento, no entanto, tais exemplos eram totalmente negligenciados, e na verdade, evitados pela tradição cristã que suprassumiu a tradição judaica antiga.

Mas, a despeito deste pouco uso dos relatos históricos do judaísmo antigo, a despeito também de toda a tradição cristã que se apropriava da história judaica, podemos ver nesta última citação de Maquiavel a indicação do que até agora tentamos demonstrar. $O$ judaísmo antigo, veterotestamentário, expressa uma leitura da religião que se coaduna à busca da defesa da pátria e de sua expansão. Nos "Discorsi", ao dizer no livro III: "Se lermos a Bíblia, interpretando-a como é propício e devido...", Maquiavel pode estar indicando a resposta de sua própria interpelação no livro II ao dizer: “... se se levasse em consideração que a fé é compatível com a grandeza e a defesa da pátria, se veria que é devida para com a boa religião amar e honrar a pátria, e assim nos prepararíamos para defendê-la." 
No entanto, na tradição cristã que Maquiavel presencia em seu tempo, o judaísmo antigo não passa de um estágio primitivo, mas importante, para a ascensão da verdade religião.

\section{Conclusão}

Nos termos indicados no transcurso de todo este texto, buscamos demonstrar como o judaísmo antigo, pelo menos em seus mais destacados traços político-religiosos expressos no chamado velho testamento, foram obliterados, transformados e adequados à realidade do devir histórico. Tais mudanças foram ligações entre a própria tradição judaica e as mudanças que o mundo sofreu desde a Antiguidade até o Renascimento. A partir disto, demonstramos, mesmo que em termos sucintos, que o judaísmo antigo, ou veterotestamentário, pode ser visto à luz das diretrizes e dos apontamentos maquiavelianos do papel da religião na constituição, manutenção e defesa de uma nação.

O assunto da religião nos textos de Maquiavel é uma seara fértil e que apresenta diversas facetas passíveis de discussão e ponderação, assim como o judaísmo antigo, em suas diversas expressões religiosas intrinsecamente ligadas às constituições políticas que estabeleceram a nação israelita. Sendo assim, temos ciência de que o assunto não foi de forma alguma encerrado, mas que apesar do caráter sucinto de nossa explanação, os termos que assentam a discussão foram satisfatoriamente expostos. 


\section{Referências bibliográficas}

ALMEIDA, João Ferreira de. Trad. A Bíblia Sagrada (revista e atualizada no Brasil) 2 ed. São Paulo. Sociedade Bíblica Brasileira, 1993.

BEVAN, Edwyn R. Hellenistic Judaism. In: SMITH, George Adam e all. The legacy of Israel. Oxford: Oxford University Press, 1927.

CAZELLES, Henri. História política de Israel: desde as origens até Alexandre Magno. Tradução de Cácio Gomes. São Paulo: Paulinas, 1986.

CAMPOS, Cyro de Moraes. História do judaísmo antigo. São Paulo: Edições Autores Reunidos Limitada, 1961.

DAHAN, Gilbert. Les intellectuels chrétiens et les juifs au moyen âge. Paris: Les éditions du CERF, 2007.

D'ISTRIA, Gérard Colonna; FRAPET, Roland. L'Art politique chez Machiavel. Paris: Vrin, 1980.

GUKOUSKJ, Matteo A.. Giovanni Pico della Mirandola: uomo del medievo o del rinascimento? In: ISTITUTO NAZIONALE DI STUDI SUL RINASCIMENTO. L'opera e Il pensiero di Giovanni Pico della Mirandola nella storia dell'Umanesimo. Convegno Internazionale. Firenze: Istituto Nazionale di studi sul Rinascimento, 1965. Vol. II.

HERRMANN, Siegfried. Storia d'Israel: I tempi dell'antico testamento. Traduzione dall'edizione tedesca di Antonio Bonora. Brescia: Editrice Queriniana, 1977.

HOBBS, T. R. L'arte della guerra nella bibbia. Traduzione di Licia Minniti. Asti: Piemme, 1997.

KRISTELLER, Paul O. Ocho filósofos del renacimiento italiano. Traducción de María Martínez Peñaloza. Madrid: Fondo de Cultura Económica, 1996.

LIVERANI, Mario. Oltre la bibbia: storia antica di Israele. 5 ed. Roma: Editori Laterza, 2006.

MACHIAVELLI, Niccolò. Opere. A cura di Corrado Vivanti. Torino: Einaudi-Gallimard, 1997.

MENDELS, Doron. The rise and fall of Jewish nationalism. Princenton: Doubleday, 1991.

NEUSNER, Jacob. Judaism and Christianity in the age of Constantine: history, Messiah, Israel, and the initial confrontation. Chicago: The University of Chicago Press, 1987.

PETUCHOWSKI, Jakob J. "I nostri maestri insegnavano...”: Storie rabbiniche scelte. Traduzione di Clara di Zoppola. Brescia: Editrice Morcelliana, 1983.

PICO DELLA MIRANDOLA, Giovanni. De hominis dignitate - Heptaplus - De Ente et Uno. A cura de Eugenio Garin. Firenze: Vallecchi Editore, 1942.

RENCKENS, H. SJ. A religião de Israel. Tradução de Frei Godeberto Crijns, O.F.M. Petrópolis: Vozes, 1969. 
SCHÄFER, Peter. Histoire des juifs dans l'antiquité. Traduit de l'allemand par Pascale Schulte. Paris: Les Éditions du CERF, 1989.

SCHIMMEL, Harry C. The oral law: a study of the rabbinic contribution to Torah She-Be-Al-Peh. 2 ed. Jerusalem: Feldheim Publishers, 1973.

SCHOLEM, Gershom. Le grandi correnti della mistica ebraica. Traduzione di Guido Russo. Milano: Einaudi, 1993.

Les origines de la Kabbale. Traduit de l'allemand par Jean Loewenson. Paris: Aubier-Montaigne. 1966.

SULLIVAN, Vickie B. Machiavelli's three Romes: religion, human liberty, and politics reformed. DeKalb: Northern Illinois University Press, 1996.

WEBER, Max. Le Judaïsme antique. Traduit de l'allemand par Freddy Raphaël. Paris: Librairie Plon, 1970.

Autor(a) para correspondência: Marcone Costa Cerqueira, Universidade Federal de Santa Catarina, R. Eng. Agronômico Andrei Cristian Ferreira, s/n, Trindade, CEP 88040-900, Florianópolis - SC, Brasil. markantfilos@yahoo.com.br. 